wary. They would run to one side to permit the passage of the automobile but rarely moved farther than $20 \mathrm{~m}$ away and (after a brief period) would resume feeding. My use of high-beam headlights on the vehicle did not seem to affect the animals differently.

I was unable to observe any sign of conflict - or other social interaction amongst the hares. Each seemed more intent on feeding than on the presence of observers or other jack-rabbits.
'ACORN, J. 1980. 83A-6 Gull Lake, in D Spaulding (Editor), A Nature Guide to Alberta, Hurtig Publishers, Edmonton.

${ }^{2}$ BANFIELD, A. W. F. 1974. The Mammals of Canada, University of Toronto Press, Toronto.

3JACKSON, J. W. 1980. More Jack Rabbits. Blue Jay 38:267.

${ }^{4}$ KREBA, R. 1980. Fearless Jack Rabbits Blue Jay 38:130-131.

${ }^{5}$ LAHRMAN, F. W. 1980. A Concentration of White-tailed Jack Rabbits. Blue Jay 38: 130 .

\title{
RIVER OTTER SIGHTINGS IN SOUTHERN SASKATCHEWAN
}

GLEN SUGGETT, 235 Lockwood Street, Winnipeg, Manitoba. R3N 1S1 and RIAN KEATING, Prairie Wildlife Interpretation Centre, P.O. Box 10, Webb, Saskatchewan. SON $2 \times 0$.

Two separate sightings of River tters were made in the prairies of outhern Saskatchewan in summer 980. Glen Suggett observed a single iver Otter on August 25 at the north nd of Moose Mountain Lake in the outheastern corner of the province. He nd Brian Keating observed another on ctober 4 at the mouth of Swift Current reek, where it enters the South Sasktchewan River. Otters are easily istinguished from mink, which they semble in colouration, by their larger ze and characteristic loping gait when inning on land.

Banfield's Mammals of Canada iggests that the River Otter is xtirpated in the prairie region of anada, but otters have been known to avel great distances in search of itable habitat. The north end of Moose ountain Lake, where Moose Mountain
Creek enters, and the mouth of Swift Current Creek both provide habitat that fulfills the otter's needs. Moose Mountain Creek, interrupted by several Beaver dams, retained a good supply of water, in spite of the drought experienced last summer. The lake, creek, and adjoining marshlands provided an abundance of amphibians and fish, the mainstays of the otter's diet. Numerous White Pelicans, Doublecrested Cormorants, and Great Blue Herons were also observed partaking of this source of protein rich food. Swift Current Creek similarly supplied a healthy population of Leopard Frogs, Minnows and other coarse fish, in addition to an assured supply of water. It lacks the concealment of the emergent vegetation found in Moose Mountain Creek, but it is an isolated spot characterized by steep valley sides, patches of dense brush, and a thin band 
of trees along the length of the creek. Otters will utilize former Beaver and Muskrat lodges or bank burrows, available along both creeks, as denning sites. They are usually most active at night, but may be observed during the day in areas where they are seldom disturbed. The two sightings this pas summer were made in mid-morning.

If anyone has observed other Rive Otters on the prairies, or would lik further information about the River Otte please contact the junior author, Bria Keating.

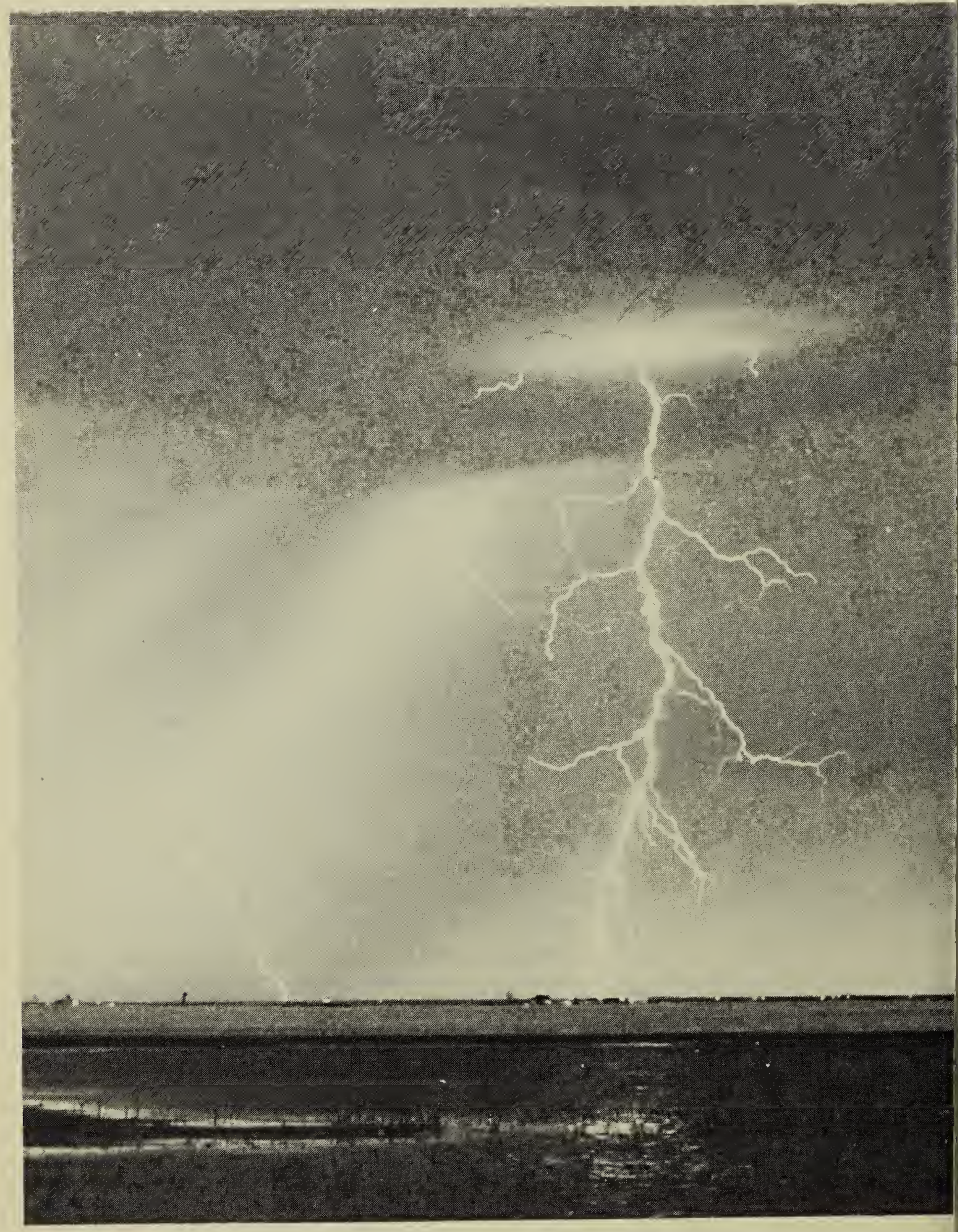

